PLEASE NOTE! THIS IS SELF-ARCHIVED VERSION OF THE ORIGINAL ARTICLE

To cite this Article: F. Adaikalam, S. Juvonen, P. Marjanen (2018) PERSPECTIVES OF EARLY CHILDHOOD EDUCATION IN INDIA AND FINLAND, INTED2018 Proceedings, pp. 5388-5394.

doi: 10.21125/inted.2018.1273

URL: https://library.iated.org/view/ADAIKALAM2018PER 


\title{
PERSPECTIVES OF EARLY CHILDHOOD EDUCATION IN INDIA AND FINLAND
}

\author{
Francis Adaikalam ${ }^{1}$, Sanna Juvonen², Päivi Marjanen² \\ ${ }^{1}$ Loyola College, Chennai (INDIA) ${ }^{2}$ Laurea University of Applied Sciences (FINLAND)
}

\begin{abstract}
The article introduces experiments based on the project called Finnish and Indian Wellbeing through Education (FINDIgATE 2016-2017) and aims to view how educational systems work in India and Finland. The aim of this article is to reflect and compare Indian and Finnish early childhood education system. One important approach in Finnish ECEC is child-centred approach, which takes into account the well-being of the child, and we argue that child-centred approach is needed in India as well. In this article, child-centred approach is defined as a pedagogic choice and delimitation, which emphasizes children's ideas and children's enthusiasm, learning and perception, and supporting all of it with the right methods and choices. Child-centred approach strongly believes in the child's abilities and potential. This approach is included as a key element in child's voluntary and planning activities, which regulates goals, content as well as self-realization [1]. Respect and equality of the child's individuality is the premise of the child-centred thinking. Every child is accepted as they are and every child is as valuable and important as the other one. [2].
\end{abstract}

Early childhood education in India is a complex one whereas in Finland it is considered as a basis for public services, which is organized with a national core curriculum. The aim of the Finnish early childhood education is to promote child's holistic growth, development and learning. Local curriculum is based on the national core curriculum, which provides a common base as references to the legislations for governing early childhood education and care as well as instructions for preparing and developing local curricula. In India, it is determined by socio-economic factors, regions and size of population since Early Childhood Education and Care (ECEC) as officially termed, is unregulated.

Finnish educational success story and its positive impact on a child's well-being provides possibility to implement the Finnish educational model. Still when compared to India, which boasts of a huge population, its regional differences and the sheer quantity of children in the school-going age, would it be possible to compare and understand the differences between India and Finland? Could Finland success in educating children and taking care of education system of early childhood as a model to adopt? Can a child be seen as a holistic human being, whose well-being and development are taken into account? These are some of the questions addressed in this article. Though challenging, it discusses how a Child-centred approach is both beneficial and rewarding.

Keywords: Child-Centred Approach, Early Childhood Education and Care (ECEC) in Finland, Early Childhood Care and Education (ECCE) in India

\section{INTRODUCTION}

Context of this study is early childhood education in promoting child well-being in the India and Finland. There are significant research studies carried out on well-being. Varying approaches such as political, economic, social, cultural contexts and time periods, as well as scientific and academic fields focusing on well-being research benefits and challenges. [3], [4], [5]. Countries define well-being in different ways and they are linked to other diverse factors e.g. on existing national policies, the nature of welfare and service provision and the cultural understanding of family and its structure. [6] Schues and Rehmann-Sutter [7] define that child well-being is related to the physical, mental, personal, cultural and social development of a child, which results in a meaningful life with other human beings.

Indian and Finnish societies represent two different situations in early childhood education and care but it does not mean that countries would not share the common understandings of childhood as a valuable and important time of the life. Finnish society is monitoring early childhood education and 
care by different laws that define how, where and when early childhood education and pre-schooling needs to be arranged and in what kind of contents. Finnish Ministry of Education and Culture has the overall responsibility for early childhood education and care including pre-primary education and for India it is the Ministry of Women and Child Development. Finland has developed its early childhood education system for years to achieve the current situation. Actually, the law for Early Childhood Education and Care (ECEC) was created in 1973 and since then its main target has been to provide care, educational aspect and teaching for children under school age. Formal recognition for Indian early childhood education and care has been initiated with an Early Childhood Care and Education (ECCE) policy guideline, curriculum framework and quality standards in the year 2013.

FINDIgATE-project offered a good study environment for Indian and Finnish masters' degree students to know, get familiar and to initiate research on educational systems and its influence on child's wellbeing in India and in Finland. For an easy understanding on Indian reality, centers for the age group between 3-6 years are taken into account. Number of pre-school centers are collected from multiple sources ICDS database for Government run pre-schools. Besides Internet -search and local search service provider's database are tapped to know the volume of pre-school players in private sector. Physical mapping is done in a high-density area in Chennai city just to count the number of preschools. Additionally visits to government run centres, private centres and centre run by non-profit institutions are made to collaborate and triangulate the existing literature.

In Finland, early childhood education is organized mostly by public services and it follows the national core curriculum. Whereas in India it is a complex reality with both public and private institutions offering the services. According to the Finnish Ministry of Social Affairs and Health [8], [9] Finnish children under seven years have the right to public day care service and this is one of the main element in the Finnish family policy. It has promoted mothers' employment and gender equality. In addition, it has also supported one-year-long pre-school period to ensure children's well-being and learning. [8], [9]. In India, Child's right for care and development is not mandatory and universal, except for some sections under the law. Rather, the State is expected to fulfil and to realise its duty progressively according to Part IV of the Indian Constitution, shortly called as Directive Principles of State Policy. Early childhood care and education services in India are offered up to six years of age through Integrated Child Development Services (ICDS).

\section{PERSPECTIVES OF EARLY CHILDHOOD EDUCATION IN FINLAND AND INDIA}

Policymakers in European Union consider Early Childhood Education and Care (ECEC) important in providing a basis for successful lifelong learning [10]. In countries with a unitary system, like in Finland, ECEC services are integrated in to one system for children from birth to compulsory school age. ECEC plays a central role in fostering children's educational success, preventing early schoolleaving (drop-out) and tackling social inequalities, when access to high quality and inclusive services is provided to all children and their families. [11].

In Finland early childhood education and care means ensuring educational interaction and appropriate living environment for young children. Its aim is to promote a balanced growth, development and learning. Furthermore, the concept of EduCare in Finland consists of small children's day-care needs in addition to the educational perspective. It describes more widely in the ECEC model of a Nordic welfare state, where play is a central tool of pedagogical activities. Care, education and instruction have been combined to form an integrated whole. According to the Act on Children's Day Care, the objectives of day care are to support parents in their responsibilities to raise their children and to promote children's personal and balanced development. [12] Early childhood education and care is the first stage of organised instruction for most of the children and it plays an important role in a child's development. The majority of 3-4 year-olds in OECD countries are enrolled in early childhood education and care. [13].

European Quality Framework for ECEC highlights a broad vision of quality that requires qualified staff. Their initial and continuing training enable them to fulfil their professional role. Supportive work conditions are also needed, including professional leadership, which creates opportunities for observation, reflection, planning, teamwork and cooperation with parents. Well-educated and competent staff are are playing a key role to fulfill the holistic framework, that values and connects the 
concepts of care and education in providing ECEC [11], [10]. Educated staff are more likely to provide high-quality pedagogy and stimulating learning environments, which foster child's development [11]. European Quality Framework is in line with the official requirements for competent staff in Finnish ECEC. Finnish day care centres have multi professional staff and at least one third of day care professionals need to have Bachelor or Master degree in Education or Social Sciences and others need to have upper secondary education [14].

Whereas in India, the concept of early childhood care and education and its operations are wide. Government of India for its operational purposes baskets all concepts relating to early childhood and care in one umbrella though there are conceptual differences. * [15] ECCE services in India (ECEC in Finland) are offered through public and private institutions and there are no harmonized activities across service providers [16]. Both Provincial and Federal Governments provide ECCE through public schemes, and statutory mandates such as Integrated Child Development Scheme (ICDS), Sarva Shiksha Abhiyan (SSA), National Program for Education for Girls at Elementary Level (NPEGEL), Rajiv Gandhi National Crèche Scheme for Working Mothers and through acts such as The Mines Act (1952), The Factories (Amendment) Act (1987), Plantations Labour Act (1951). Building and other Construction Workers' (Regulation of Employment and Conditions of Service) Act, 1996 and The Mahatma Gandhi National Rural Employment Guarantee Act (2005). Apart from this, non-profit agencies offer services either, for free or for a nominal cost. The Private entities provide it to their employees to fulfil legal obligations or to children who are admitted to their educational institutions. Providing ECCE is not a mandated universal service in India and moreover there is no single or centralized agency to coordinate these services. Hence, getting numbers from multiple agencies except from ICDS services is near impossible. For example, Early Childhood Care and EducationICDS scheme is catering to 103 million children between the age group of 6 months to 6 years [17], [16]. The services are offered based on the age group and for each stage. Specific interventions are recommended in the following way i) Conception to Birth- for Safe childbirth, child protection and nondiscrimination ii) Birth to Three years- for survival, safety, nutrition including infant and young child feeding practices for 6 months, opportunity for psycho-social stimulation and nurturing, stimulating environments in homes and child care centres and iii). Three years to Six years - for protection, health care, appropriate play-based preschool education.

\section{PEDAGOGICAL APPROACH}

Finnish early childhood pedagogy is based on a defined value gives importance to childhood and learning. Pedagogy means, 'multidisciplinary and professionally targeted activities for children's which support wellbeing and learning'. [18] Pedagogy contains at least some of the cornerstones, which have been stressed during last decade. It includes a) play, b) child-centred approach, c) active use of learning environments and d) strong theory based orientation.

Play has an essential role in Finnish early year's pedagogy. Significant role of play are justified because according to many research studies children can handle their feelings by playing. It not only generates pleasure for children, but also gives a possibility to handle traumatic experiences. Finnish pedagogy stresses that play can develop thinking, language and imagination which are connected to child health and well-being, social skills and emotional life. [e.g.19].

Child-centred approach is defined in Finnish pedagogy as, pedagogic choice and delimitation, which emphasizes children's ideas and children's enthusiasm, learning and perception, and supporting all of it with the right methods and choices. Child-centred approach strongly believes in the child's abilities and potential. This approach is included as a key element on child's voluntary and planning activities, which regulates goals, content as well as self-realization [1]. Respect and equality of the child's individuality are in the background of the child-centred thinking. Every child should accept such as they are. [2]. Respect and equality of the child's individuality are in the background of the child-centred thinking.

$*(E C C E)=$ Early Childhood Education $(E C E)=$ Early Childhood Development $(E C D)=$ Early Childhood Care and Development $(E C C D)=$ Integrated Child Development $(I C D)$, all promoting holistic development of young child. 
Apart from this, research and development on active and rich learning environments have been in important role in Finnish pedagogy. According to National Core Curriculum for early Childhood Education [18], learning environments means spaces, places, communities, practices, tools and supplies that support children's development, learning and interaction. The concept of learning environment includes, among others, physical, psychological, early childhood education and the social dimension. According to our understanding especially outdoor activities, active and versatile use of spaces and rich play environments are important and unique part of Finnish pedagogy.

Finnish early education pedagogy varies across different theoretical perspectives and some main contributions are from Fröbel, Piaget and Vygotsky [e.g.20]. They emphasized social pedagogical perspective even though new curriculum is increasingly emphasizes individual assessment. At present, the Nordic countries have sought to change their models of childcare. The emphasis is on child's play to promoting learning and knowledge in specific areas such as languages', mathematics and science, technology, metacognitive learning, social skills, cultural awareness and entrepreneurship [21].

Whereas in India, there was no specific norm developed for ECCE by statutory authorities except for operationalizing Integrated Child Development Scheme (ICDS) in India. The concept of pedagogy has not rooted in the official documents in designing curriculum except in the ECCE policy document, which equates pedagogy for an inclusive approach. For example, even last of the child with a disability in the remote rural areas must be reached in terms of access, participation and support. Voluntary agencies and provincial Governments have experimented and demonstrated it in isolated places. Recently, the policy on ECCE notified in 2013 by the Ministry of Women and Child Development. Government of India has listed the key areas to focus, some of the item includes, i) Access with equity and inclusion in programs and interventions across service providers; ii) Improving quality ( minimum specifications, quality standards, regulation, curriculum, play and learning material, programme assessment and child assessment; iii) Institutional and Implementation Arrangement (ECCE cell, National ECCE Council \& Plan of Action).

ECCE policy has believes that child's development is paramount. ECCE policy formulation has resulted in developing framework for Early Childhood Care and Education, henceforth called as India's Curriculum Framework (ICF). This framework tries to address developmental need of the child with a pedagogical approach. It advocates for diverse syllabus, which would ensure better childcare and quality learning. ICF has 3 sections with Section 1 on rationale and theoretical foundation focusing on pedagogy; Section 2 on goals for different domain of development and Section 3 on planning, role of parents, caregivers, teachers, play materials and assessment procedure etc.

ECCE curriculum Framework [16] mentions "learning is an active and interactive process in which children learn through play and through interaction between children and more experienced others. Children are actively engaged in their social and cultural experiences". Pedagogy and Principles of Early Learning and Development proposed in the curriculum framework are premised on this ideological position. Pedagogy must be ingrained in programme planning itself with a belief that the "children learn best through play and learning by doing". The play and activity it says must be planned according to "the needs, interests, abilities and social context of the children for whom it is planned" and adults are just facilitators in the whole process. It has followed 'life cycle approach' for care and learning. Focus will be on Care and Protection from birth to three years and 'school readiness skills' between three to six years [15], [16].

\section{REFLECTIONS IN INDIA AND FINLAND}

First, what are the intention of schools? Is it to develop the child in a holistic way? Does it offer overall development? Does it promote child-centred approaches? These questions need to be answered while discussing about the way pre-schools are in operations. One would say that parents especially in India expect their children to perform certain unimaginable academic activities at early age. Peer pressure and multiple social realities they live in has entangled them to demand such unimaginable activities. Likewise, parents expect that their wards meet their dreams. Parents want quick fix solution and expect their children to learn in a quick pace. This pushes children, particularly in India, to follow what their parents want and almost all children end up in losing their own imagination and dreams. In the same way, India's complexity with regard to culture, language, ethnicity, gender and caste coupled with educational requirements brings many challenges for childhood care and education. Indian federal state devolves power both to Central (Union) and State (Province) Governments (Constitution of India, Part XI, Section 1). Education comes under concurrent list, which means, both Union and the 
province would work together. But the major revenue collection goes to the Union Government under the existing tax regime. It means that the Union Government would have greater leverage over financial aspects even though the provincial Governments are mandated to ensure social welfare and health care for the people. Federal Government, provincial Governments, local municipalities, nongovernmental agencies and private entities run the pre-school centers in India. Hence, their intent, plan and operations vary across spectrum. To understand the complexity in India, the discussion focuses on the intended result and on how pre-schools are operated.

There is also slow erosion of the true spirit of child learning in Finland. Nordic Educare thinking, with elements of care, education and teaching, along with social development, play and peer relationships, are also disappearing from early childhood education. Formal teaching and learning, on the other hand, are emerging trends. [24] [21]. Holistic, philosophical perspective for child well-being define child wellbeing as being related to not only the physical but also for mental, personal, cultural and social development of a child [7]. Even though in the Finnish national curriculum well-being is mentioned many times, it has focussed only on health and security issues.

Second reflection is, how does the pre-schools operate in India and Finland. In India, the high market players are operating in all urban centres either through franchise model or it has been managed by a single owner. For example, Chennai city, which has a population of close to 7 million residents with 26,903 inhabitants per square kilometer $(69,680 /$ mile sqr) has close to 150 preschools. Chennai North and Central has the maximum number of pre-schools numbering 69. Whereas, Chennai South has 29 and Chennai West is numbered as 44 . There are 19 centres in one particular area, which has 77 streets (Choolaimedu, Ward 109, Zone 9). Research report titled as "Indian Preschool Market Forecast", in the year 2011 mentions that Indian preschool market has been witnessing rapid growth for the past few years due to increase in income, rising number of working mothers, increasing trend of nuclear families, and escalating demand for high quality preschool education for toddler. The preschool market will reach to USD 1,833 Million by 2014, growing at a CAGR of around $13 \%$ during 2011-2014. Growth is 36\% per annum [22]. Preschool or childcare market in India is set to grow at a Compound Annual Growth Rate (CAGR) of 21.84\% during the period 2016-2020. Business standard 20th January 2013 reported that pre-school industry in India is estimated to gross about Rs 4,004 crore and is likely to grow more than 25 per cent by 2012. [23]

These unregulated and market demand need drives how pre-schools operated in India. No national laws or guidelines except for the two recent ones from National level by the Ministry of Women and Child Development (2013), by NCPCR and by Draft Code of Regulations for Play Schools Govt. of Tamilnadu (2015). There are many lofty ideas mentioned in the policy document. But in practical terms the existing structure is cemented on a 'parroting system' and not allowing the children to play, think and enjoy their living environment. Child's cultural and linguistic aspects are least considered; the training is giving importance to writing even at the age of three. Homework (worksheets and tasks to be completed at home are assigned to children every day) is mandatory and heavily loaded; fine motor skills training is missing; No outdoor play is encouraged since child's cloth become dirty, child can get hurt and catch infection. These aspects not only prevalent in the privately run centres but also at the Government run pre-schools. Only handful of schools or centres allows children to express their freedom across India.

Compared to the above-mentioned situation described in Indian "pre-school market" and huge population, it is almost impossible to compare early-childhood education in India and in Finland. Finnish population is homogeneous. Hence, it is easier to provide "one for all" curriculum. Finnish parents also agree that Finnish early-childhood education system enhances equality and wellbeing of children. Families trust towards public sector, which provides daycare place for every children under seven years old. Additionally, it is not common to choose a special daycare centers for the child, which offers a unique specialized activities for children since basic curriculum is the same across the centres. The public sector offers the daycare places for the families, based on the place of living and home address. As pedagogy approach is getting narrowed, changes are also taking place in the services offered by public sector for children and families. Especially private pre-school sector increasing the position in the service structure in recent years. Besides, more emphasis is for continuous quality assessment, customer satisfaction assessment and evidence- based development. 


\section{CONCLUSION}

Viewed from public good point of view the state has obligation to protect children and offer universal services for their development. Because universal coverage with a state obligation is the key for ensuring overall wellbeing for children. This is reiterated in the documents produced by Government of India, Finland and through various research studies. ECCE policy and syllabus framework in India stress the need for a universal access with equity and inclusion, which is, still a mirage children belonging to varied sections. Rather than fulfilling State's constitutional duty to protect and promote child's development, the Indian Government encourages private and non-governmental services provision, as it has not spelt out how this will be in operationalized [15]. This can encourage the market to play more aggressively for the privileged section and derail constitutionally mandated fraternity and equality.

Finnish policy makers and childhood researchers have had discussions of school entry age. In Finland children are relatively old (7 years), compared to the other European or Indian children, when starting the primary school. This would naturally produce changes in early childhood education: if pre-primary school starts earlier children would need to practice skills which support school readiness. There is a pressure to get Finnish citizens earlier to the working life. For example, if a child starts their primary school later, they would arrive to the job market later. Ageing society in Finland needs more taxpayers! Hence, the dilemma to admit child at early age to school still lingers. Still childhood itself is an essential time to grow up and develop personality and skills needed later in the society. Very easily parents tend to admire children's capability to behave independently and child's right to play isn't always valued enough. The pressure of achieving academic skills decreases the knowledge of childcentred learning and the meaning of play and doesn't support wellbeing of child in Finland.

Furthermore, Studies have shown that Children having greater social and emotional competencies experienced better outcomes across multiple domains, including educational attainment and later employment [25] Thus focus on socio-emotional competencies has not only benefits individual child but also country's economy. Elements such as access to child care centres, peer learning, gamification, painting and drawing, reading and listening stories, group plan and exposure to multiple environments would not only kindle their imagination but also ensure overall wellbeing for the child. This must be facilitated keeping with existing socio-cultural realms in the respective countries for a overall development of the child. As discussed, child-centered approach is part of the Finnish pedagogy. This facilitates child to be independent and realise their self to achieve their full potential. The child-centered approach not only provides platform for the child to play but also kindles their imagination, improves linguistic ability and ensures better wellbeing. Hence, Early Childhood Education and Care can be best achieved if systems are child-friendly.

Childhood is a meaningful time of the life. Child-centred approach sees child in a holistic human being framework, whose well-being and development as a whole person is taken into account. It should be aim in all over the world, also Finland and India.

\section{ACKNOWLEDGEMENTS}

FINDIgATE - Finnish and Indian Wellbeing through Education was funded by Asia programme, Finnish National Agency for Education EDUFI

\section{REFERENCES}

[1] J. Kinos, Lapsilähtöinen varhaiskasvatus, In E. Hujala (ed.) Puheenvuoroja lapsista ja varhaiskasvatuksesta. Jyväskylä: Gummerus Kirjapaino Oy, 30-38. 2001.

[2] J. Hytönen, Lapsikeskeinen kasvatus. Helsinki: WSOY. 1992.

[3] V. Heaslip \& J. Ryden (Eds). Understanding Vulnerability: A Nursing and Healthcare Approach. Oxford: Wiley \& Sons. 2013.

[4] P. Liamputtong, Researching the Vulnerable. A Guide to Sensitive Research Methods. London:Sage Publications. 2007. 
[5] D. Narayan, R. Patel, K. Schafft, A. Rademacher, \& S. Koch-Schulte. Voices of the Poor: Can Anyone Hear Us? World Bank Publications. Washington: USA, 2000.

[6] P. Marjanen, A. Ornellas \& L. Mäntynen. Determining Holistic Child Well-being: Critical Reflections on Theory and Dominant Models. Child Indicators Research, 1-15. DOI:10.1007/s12187-016-9399-6, 2016.

[7] C. Schues \& C. Rehmann-Sutter, The Well- and Unwell-Being of a Child. Topoi, 32(2), 197-205, 2013.

[8] Sosiaali - ja terveysministeriö [STM], Lapsi- ja perhepolitiikka Suomessa. Sosiaali-ja terveysministeriön esitteitä 2013:9. Helsinki: Sosiaali -ja terveysministeriö. 2013. Retrieved from http://julkaisut.valtioneuvosto.fi/bitstream/handle/10024/69914/URN ISBN 978-952-00-33743.pdf

[9] Sosiaali-ja terveysministeriö [STM], Varhaiskasvatustutkimus ja varhaiskasvatuksen kansainvälinen kehitys, Sosiaali- ja terveysministeriön selvityksiä 2007:6. Helsinki: Sosiaali-ja terveysministeriö. 2007 Retrieved from http://julkaisut.valtioneuvosto.fi/bitstream/handle/10024/72989/Selv200706.pdf?sequence=1\&is Allowed $=y$

[10] European Commission, Brussels. 2011. Retrieved from http://eurlex.europa.eu/LexUriServ/LexUriServ.do?uri=COM:2011:0066:FIN:EN:PDF

[11] B. Peleman, B. Jensen, \& J. Peeters, Innovative approaches to continuous professional development in early childhood education and care, A European perspective. European Journal of Education. 2018.

[12] OECD, Early Childhood Education and Care Policy in Finland. Background report prepared for the OECD, Thematic Review of Early Childhood Education and Care Policy. 2000. Retrieved from http://www.oecd.org/finland/2476019.pdf

[13] OECD. Starting Strong IV Early Childhood Education and Care Data Country Note Finland. 2016. Retrieved from https://www.oecd.org/edu/school/ECECDCN-Finland.pdf

[14] STAKES, National Curriculum Guidelines on Early Childhood Education and Care in Finland. 2004. Retrieved from https://www.julkari.fi/bitstream/handle/10024/75535/267671cb-0ec04039-b97b-7ac6ce6b9c10.pdf?sequence=1

[15] Ministry of Women and Child Development, Government of India declares that Early Childhood Care and Education, Through notification No. 6-3/2009-ECCE, National Early Childhood Care and Education (ECCE) Policy, 2013.

[16] Ministry of Women and Child Development, National Framework for Early Childhood Care and Education (ECCE) Curriculum Framework, Government of India. 2013. Retrieved from http://www.wcd.nic.in/sites/default/files/national ecce curr framework final 03022014\%20\%2 82\%29.pdf

[17] Ministry of Women and Child Development, Gol, Annual report 2014-15. Retrieved from http://www.wcd.nic.in/sites/default/files/AR2014-15.pdf

[18] Varhaiskasvatussuunnitelman perusteet, National Core Curriculum for Early Childhood Education and Care. 2016. Retrieved from http://www.oph.fi/download/179349 varhaiskasvatussuunnitelman perusteet 2016.pdf

[19] K. Karila, J. Kinos \& J. Virtanen, J. (eds.) Varhaiskasvatuksen teoriasuuntauksia, Juva: WS Bookwell Oy. 2001. Retrieved from http://www.oph.fi/english/curricula and qualifications/early childhood education and care

[20] Opetushallitus, Leikki esiopetuksessa: tukimateriaali, 2016. Retrieved from http://www.edu.fi/download/181135 leikki esiopetuksessa tukimateriaali.pdf

[21] M. Alasuutari, A.-M. Markström and A.-C. Vallberg-Roth, Assessment and documentation in early childhood education. London: Routledge, 2014.

[22] Business Consultancy Services. Preschool Market in India to grow at 13\% CAGR. 2011. Retrieved from http://www.rncos.com/Press Releases/Preschool-Market-in-India-to-grow-at-13CAGR.htm. 
[23] Business Standard. KIT: India's pre-school education market. 2013. Retrieved from http://www.business-standard.com/article/management/kit-india-s-pre-school-education-market109091500058 1.html

[24] A. Niikko, Finnish daycare: Caring, education and instruction. In J. Einarsdottir and J.T. Wagner (eds.), pp. 133-158, Nordic Childhoods and Early Education: Philosophy, Research, Policy, and Practice in Denmark, Finland, Iceland, Norway, and Sweden. Greenwich, CT: Information Age Publishing, 2006.

[25] D.E. Jones, M. Greenberg \& M. Crowley, Early Social-Emotional Functioning and Public Health: The Relationship Between Kindergarten Social Competence and Future Wellness. American Journal of Public Health, 2015 105(11), 2283-2290. 